\title{
Serum metabolite concentrations and enzyme activities in finishing bull calves fed different types of high-grain diets
}

\author{
Cristina Castillo', Joaquin Hernandez ${ }^{1,4}$, Victor Pereira', Patricia Vazquez ${ }^{1,5}$, Juan Sotillo², \\ Marta Lopez-Alonso', Marta Miranda ${ }^{3}$ and Jose L. Benedito ${ }^{1}$ \\ 'Departamento de Patologia Animal, Facultad de Veterinaria, Universidad de Santiago de Compostela, Spain, \\ ${ }^{2}$ Departamento de Medicina y Cirugia Animal, Facultad de Veterinaria, Universidad de Murcia, Spain, ${ }^{3}$ Departamento \\ de Ciencias Clinicas Veterinarias, Facultad de Veterinaria, Universidad de Santiago de Compostela, Spain, ${ }^{4}$ ECBHM \\ Diplomate, ${ }^{5}$ Research Department, CESFAC, Madrid, Spain
}

\begin{abstract}
Between the ages of 23 and 35 weeks, various serum metabolites and enzymes were monitored in three 10-animal groups of double-muscled Belgian Blue bull calves maintained in a feedlot in Galicia (NW Spain) on high-grain finishing diets that mainly differed in whether the grain used was predominantly maize (group M), predominantly barley (group B), or a mixture of maize and barley in approximately equal proportions (group MB). The parameters determined were glucose, non-esterified fatty acids (NEFA), total serum protein concentration (TSP), albumin, serum urea nitrogen (SUN), creatinine, aspartate aminotransferase (AST), and gamma-glutamyltransferase (GGT). Throughout the study period, all these parameters remained within the physiological ranges for beef under intensive conditions, and no animal ever showed clinical symptoms of ruminal alterations; indicating that none of these highgrain diets were detrimental to animal health. Although average serum NEFA, creatinine, albumin, AST and GGT levels all differed among groups, only AST can be considered as possible age-independent marker of grain-type-related metabolic alterations, since the other parameters all showed significant time $\times$ group interaction. In terms of this parameter, animals fed a MB diet behaved similarly to those fed a B diet. The absence of between-group differences in blood glucose level may reflect a genetic characteristic of this double-muscled breed. Our results, in conjunction with the best productive results obtained in animals fed de B-diet, aim us to suggest that the risk of an acidogenic diet would depend strongly on the nutritional management (in terms of crude protein (CP) and quality of straw in the ration) and not only the type of grain.
\end{abstract}

Keywords: cattle, double muscling, high-grain diets, metabolites

\section{Zusammenfassung}

\section{Serum-Metaboliten-Konzentrationen und Enzymaktivitäten in mit verschiedenen Futtermittelarten mit hohem Getreideanteil gefütterten Mastbullenkälbern}

Zwischen dem Alter von 23 und 35 Wochen wurde ein Monitoring durchgeführt der verschiedenen Serum-Metaboliten und Enzyme mit drei Gruppen zu jeweils 10 Weißblauen Belgier-Bullenkälbern mit starker Muskelfülle, die in einer Mastparzelle in Galizien (NW 
Spanien) mit Mastfuttermittelarten mit hohem Getreideanteil gehalten wurden, die sich hauptsächlich darin unterschieden, dass das verwendete Getreide überwiegend aus Mais (Gruppe M), überwiegend aus Gerste (Gruppe B) oder aus einem Gemisch von Mais und Gerste zu ungefähr gleichen Teilen (Gruppe MB) bestand. Die nachgewiesenen Parameter waren Glukose, nicht veresterte Fettsäuren (NEFA), Serum-Gesamtproteinkonzentration (TSP), Albumin, Serum-Harnstoffstickstoff (SUN), Creatinin, Aspartataminotransferase (ASTZ) und $\gamma$-Glutamyltransferase (GGT). Während des Untersuchungszeitraums blieben diese Parameter durchwegs innerhalb des für Rindfleisch unter intensiven Haltungsbedingungen physiologischen Bereichs, und kein Tier zeigte zu irgendeiner Zeit klinische Symptome einer Rumen-Veränderung, so dass keines dieser Futtermittel mit hohem Getreideanteil der tierischen Gesundheit abträglich war. Obwohl die durchschnittlichen Konzentrationen von NEFA, Creatinin, Albumin, AST und GGT im Serum in den Gruppen alle unterschiedlich waren, kann nur AST als möglicher altersunabhängiger Marker von getreidebedingten Stoffwechselveränderungen betrachtet werden, da die anderen Parameter alle eine signifikante Wechselwirkung zwischen Zeit und Gruppe zeigten. Im Hinblick auf diese Parameter verhielten sich Tiere, an die ein MB-Futtermittel verfüttert wurde, wie diejenigen, an die ein B-Futtermittel verfüttert wurde. Das Fehlen von Intergruppenunterschieden hinsichtlich des Blut-Glukosespiegels könnte ein genetisches Merkmal dieser Rasse mit starker Muskelfülle widerspiegeln. Unsere Ergebnisse, zusammen mit den besten, mit Tieren, denen das B-Futter verfüttert wurde, erhaltenen Nutzergebnissen veranlassen uns zu dem Vorschlag, dass das Risiko einer azidogenen Fütterung stark vom Fütterungsmanagement (hinsichtlich Roheiweiß (CP) und Qualitätsstroh in der Ration) und nicht nur vom Getreidetyp abhängt.

Schlüsselwörter: Rind, Muskelfülle, Futtermittel mit hohem Getreideanteil, Metaboliten

\section{Introduction}

The optimization of cereal grain utilization while maintaining normal rumen function and animal health continues to be a major challenge for the feedlot industry. Although it is widely recognized that the starch contained in small cereal grains (barley and wheat) is degraded more rapidly in the rumen than the starch in maize, little is known about whether different grains have different effects on metabolism.

The clinical chemistry profile is a valuable diagnostic tool that can be used to evaluate the internal balance. When used in conjunction with the physical examination the chemistry panel may be useful for establishing initial baseline parameters, formulating a problem or rule out list, planning nutritional options and monitoring the response to it (Russell \& Roussel 2007). In fact, in previous studies, plasma metabolite concentrations and the activities of certain enzymes involved in energy metabolism have been shown to be useful indicators of changes in the metabolic status of beef cattle and other animals (Brown et al. 2000a, Arai et al. 2003, Mori et al. 2007).

In a previous paper (Castillo et al. 2009) we described how the acid-base status and L-lactate levels of finishing bull calves was influenced by grain mix in diets with total grain contents of 45-60\%. We showed that serum L-lactate levels were almost invariably higher in calves fed a diet with barley as the main component than in calves fed a maize-based diet. Following to last article, the work described here report the influence of the same diets on other serum 
metabolic parameters, namely glucose, non-esterified fatty acids (NEFA), urea nitrogen (SUN), creatinine, total protein concentration (TSP), albumin, aspartate aminotransferase (AST) and gamma glutamyl transferase (GGT), looking for metabolic indicators connected with the nutritional protocol received by the animals.

This study was carried out in a commercial feedlot farm using animals destined for market, and covered the entire 80-day finishing period employed in the authors' region, Galicia (NW Spain). Several studies have generally focused on short-term effects $(<5$ days), but in the present study, we considered longer-term effects on these parameters. Furthermore, of course, it is of interest to know whether these easily measured indicators of systemic metabolic status are affected to different extents, if at all, by different high-grain diets used under commercial conditions. As far as we know no studies of such health variables have been carried out in which diet, as the independent variable, has been manipulated taking into account the nutritional protocols used in commercial feedlot farms, or in which health variables have been evaluated jointly with production variables.

\section{Materials and methods}

\section{Animals, feeding management and experimental design}

We studied 30 double-muscled Belgian Blue steers that had been brought to the commercial study farm (Coren SCL, Ourense, NW Spain) at an age of 3-5 weeks. Upon arrival, each animal was weighed, ear-tagged, and vaccinated against clostridial infections (with 4 $\mathrm{mL}$ of Toxipra-S7, from Hipra, Girona, Spain) and against infectious bovine rhinotracheitis, parainfluenza-3 virus, bovine respiratory syncytial virus and bovine viral diarrhoea (with $2 \mathrm{~mL}$ of Cattlemaster-4, from Pfizer, Madrid, Spain); booster doses were given 5 weeks later. The animals were also treated for endo- and ectoparasites with the recommended dose of ivermectin (Ivomec, from Merial Laboratorios, S.A., Barcelona, Spain), and were given an injection $(0.2 \mathrm{~mL}$ per $10 \mathrm{~kg})$ of a preparation containing vitamins $A, D_{3}$, and $E$ (Hipravit- $\mathrm{AD}_{3} \mathrm{E}-$ Forte, from Hipra, S.A., Girona, Spain). After medication, the calves were housed in pens with straw bedding in a sheltered, unheated barn.

Until age 14 weeks the calves were weaned to grain-based diets with a combination of milk replacer ( $1 \mathrm{~L}$ per $20 \mathrm{~kg}$ bodyweight) combined with a starter diet formulated on the farm, made up of maize (25\% DM basis), wheat (10\%), barley (25\%), soybean meal (44\% CP; $21 \%)$, soybean hulls (3\%), wheat bran ( $8 \%)$, palm oil (98\% bypass fat; $1 \%)$, barley sprouts (2\%), sweet whey powder (3\%) and vitamin-mineral premix (see footnote to Table 1; $2 \%$ ), with water and straw ad libitum (Bacha 1999). They were then allotted randomly to one of three 10-calf groups that were fed different high-grain diets during a 60-day growing period (age 14-23 weeks). Group M was fed maize as the main cereal grain and sodium bicarbonate as diet buffer; group B was fed barley as the main cereal grain; and group MB was fed equal proportions of maize and barley (Table 1). Finally, at age 23 weeks, the three groups were placed for 80 days on the finishing diets detailed at the right of Table 1.

All grains were ground in a hammer mill to a particle size less than $5 \mathrm{~mm}$. All calves had free access to feed, water and barley straw, which was chopped to a length of 7-8 cm. Fresh feed was provided once a day at 08:00 h. Throughout the study, the animals were cared for and managed in accordance with official Spanish guidelines on animal care. 
Table 1

Ingredients and chemical composition of the concentrates fed during the growing and finishing periods

\begin{tabular}{|c|c|c|c|c|c|c|}
\hline & \multicolumn{3}{|c|}{ Growing Groups } & \multicolumn{3}{|c|}{ Finishing Groups } \\
\hline & M & $\mathrm{MB}$ & B & $M$ & $\mathrm{MB}$ & B \\
\hline \multicolumn{7}{|l|}{ Ingredient, \%DM } \\
\hline Barley & 14.5 & 27.0 & 32.6 & 15.8 & 32.9 & 30.5 \\
\hline Rye & - & - & 5.0 & 6.0 & - & 6.0 \\
\hline Wheat & - & 6.0 & 10.0 & - & - & 10.0 \\
\hline Maize & 30.0 & 25.0 & 10.0 & 30.0 & 27.5 & 10.0 \\
\hline Molasses & 3.0 & 3.3 & 2.5 & 2.5 & 3.3 & 2.5 \\
\hline Sunflower meal & 4.0 & & & - & - & - \\
\hline Palm oil (98\% bypass) & 2.0 & 1.9 & 1.8 & 0.5 & 1.6 & 2.0 \\
\hline Palm kernel oil & - & - & - & 4.0 & 4.0 & 4.0 \\
\hline Soybean meal, $44 \%$ CP & 14.3 & 16.5 & 15.1 & 13.5 & 12.9 & 9.6 \\
\hline DDGS & - & - & 7.0 & - & - & 8.0 \\
\hline Barley sprouts & 2.0 & 2.0 & & - & - & - \\
\hline Corn gluten feed & 10.0 & 14.0 & 10.0 & 10.0 & 14.0 & 10.0 \\
\hline Wheat bran & 9.0 & - & - & 5.3 & - & 4.2 \\
\hline Soybean hulls & 8.0 & 1.5 & 3.2 & 10.0 & 1.6 & 1.1 \\
\hline Sodium bicarbonate & 0.6 & - & - & 0.3 & - & - \\
\hline Vitamin/mineral premix ${ }^{a}$ & 3.2 & 2.8 & 2.8 & 2.1 & 2.2 & 2.1 \\
\hline \multicolumn{7}{|c|}{ Chemical composition, \%DM } \\
\hline $\mathrm{CP}$ & 16.6 & 16.5 & 16.6 & 15.0 & 15.0 & 15.5 \\
\hline $\mathrm{CF}$ & 7.6 & 4.6 & 5.0 & 7.3 & 5.0 & 5.0 \\
\hline NDF & 21.3 & 17.5 & 19.0 & 20.8 & 19.3 & 21.6 \\
\hline ADF & 10.8 & 6.0 & 6.6 & 11.1 & 6.8 & 7.2 \\
\hline $\mathrm{EE}$ & 4.9 & 4.0 & 4.1 & 3.5 & 4.1 & 4.7 \\
\hline NFC & 50.9 & 56.3 & 54.5 & 57.2 & 56.6 & 53.1 \\
\hline Ash & 6.3 & 5.7 & 5.8 & 3.4 & 5.0 & 5.1 \\
\hline
\end{tabular}

M: maize-based diet, B: barley-based diet, MB: equal mixture of maize and barley, DDGS: maize distillers' dried grain with solubles, CP: crude protein, CF: crude fibre, NDF: neutral detergent fibre, ADF: acd detergent fibre, EE: ether extract content, NFC: non-fibre carbohydrates calculated as 100-(CP+ash+NDF+EE) a Vitamin and mineral premix containing (per kg DM premix): $10000 \mathrm{IU}$ vitamin A, $2000 \mathrm{IU}$ vitamin D, $10 \mathrm{IU}$ vitamin E, $0.4 \mathrm{mg} \mathrm{Co}, 16 \mathrm{mg} \mathrm{Cu}, 25 \mathrm{mg} \mathrm{Fe}$, $2 \mathrm{mg} \mathrm{l}, 110 \mathrm{mg} \mathrm{Mn}, 0.3 \mathrm{mg} \mathrm{Se}$, and $120 \mathrm{mg} \mathrm{Zn}$

\section{Measurements and analysis}

At the beginning of the growing and finishing periods, samples of concentrate were analysed in the farm laboratory. Acid detergent fibre (ADF) and neutral detergent fibre (NDF) were determined by the method of Van Soest et al. (1991), crude fibre (CF) as per European Union Directive 92/89/EEC, ether extract (EE) as per EU Directive 98/64/EEC, starch as per EU Directive 99/79/EEC, and ashes as per EU Directive 81/680/EEC. Crude protein (CP) was determined using the French standard method (Dumas; N×6.25: Association Française de Normalisation, NF V18-120).

Before blood sampling, the calves were examined for clinical signs of metabolic acidosis, i.e. for changes in posture or behaviour, signs of dehydration or shock (position of the eyeballs, temperatures of the oral cavity and extremities), diarrhoea, and altered palpebral reflex (Lorenz 2004).

Blood samples were collected between 09:00 and 11:00 $\mathrm{h}$ (hence after feed delivery) on day 0 (the last day before beginning of the finishing diet) and on days 3, 7, 22, 50 and 80. 
Samples were taken by jugular venous puncture and collected in Vacutainer tubes without EDTA, and were allowed to clot at room temperature for $3 \mathrm{~h}$ before centrifugation at $2000 \mathrm{~g}$ for $20 \mathrm{~min}$ and removal of the supernatant, which was stored at $-20^{\circ} \mathrm{C}$ until analysis. Serum NEFA were assayed with kits supplied by Randox Laboratories Ltd. (UK) and Spinreact SA, (Girona, Spain), respectively. All other metabolic parameters were measured using Gernon diagnostic kits from RAL S.A. (Barcelona, Spain). In all cases, appropriate controls were used. Within-run and within-day coefficients of variation were less than the limits of $5 \%$ and $10 \%$, respectively that were recommended by Lumsden (2000).

\section{Statistical analysis}

Non-normal distributions were tested for using the Shapiro-Wilk test. Analyses of variance (ANOVAs) were performed with group ( $\mathrm{M}, \mathrm{MB}$ or $\mathrm{B}$ ) as fixed effect factor and time as repeatedmeasures factor, and with the timexgroup interaction included in the model. All statistical analyses were performed using the package SPSS version 12.1 (SPSS Inc 2004). The criterion for statistical significance was $P \leq 0.05$.

\section{Results and discussion}

\section{Physical examination}

Animal performance is reported elsewhere (Castillo et al. 2009, Table 2). Briefly, the three groups did not differ with respect their final weights in the slaughterhouse although best productive performance was afforded by the barley-based diet (group B gained significantly more weight and had a lower daily intake than either group $M$ or group MB during the finishing period).

Table 2

Productive performance (means \pm SEMs) of finishing-stage bull calves (Castillo et al. 2009)

\begin{tabular}{|c|c|c|c|c|}
\hline \multirow[t]{2}{*}{ Variable } & \multicolumn{4}{|c|}{ Group } \\
\hline & $M$ & MB & $B$ & $P$ \\
\hline Initial weight, kg & $222.0 \pm 3.0^{b}$ & $232.0 \pm 4.4^{c}$ & $208.0 \pm 3.4^{\mathrm{a}}$ & $<0.001$ \\
\hline Final weight, kg & $405.0 \pm 5.5$ & $420.0 \pm 2.7$ & $416.0 \pm 4.1$ & $>0.1$ \\
\hline Average daily gain, $\mathrm{kg}$ & $1.5 \pm 0.04^{a}$ & $1.5 \pm 0.05^{a}$ & $1.7 \pm 0.03^{b}$ & 0.019 \\
\hline Daily intake, kg/d & 7.9 & 8.1 & 7.5 & - \\
\hline Feed:gain ratio & 5.3 & 5.4 & 4.4 & - \\
\hline
\end{tabular}

M: maize-based diet, B: barley-based diet, MB: equal mixture of maize and barley, Significance P of variation among groups; within each row, means with the same superscript letter do not differ significantly at the $5 \%$ level.

As expected in view of the relatively moderate grain contents of all three diets, at no time during the study did any of the animals develop clinical signs of acidosis (changes in posture or behaviour, altered palpebral reflex, or signs of dehydration such as anomalous mouth or limb temperature or eyeball position; Lorenz 2004) or of other disorders related with high grain consumption (variations in feed intake, in the frequency and amplitude of ruminal contractions or decrease in venous blood pH; Brown et al. 2000a, 2000b). The health of the animals may also have been favoured by the amount of CP in these diets, which was greater than the recommended $12-13 \%$ (Bailey \& Duff 2005) and may have acted as a pH buffer 
(Brown et al. 1998, Castillo et al. 2008). Additionally, the forage fibre source employed, barley straw, contains more long-fibre NDF than traditional silage forage, and may thus be more effective in promoting chewing activity and saliva secretion (Krause et al. 1998).

\section{Serum parameters}

The group means and standard errors of each parameter studied on each sampling date are listed in Tables 3 and 4 together with the corresponding ANOVA results. Taking the study group as a whole, all these parameters except AST showed significant variation among sampling dates. In particular, serum glucose tended to fall with increasing calf age in group $B$ and, after the first week, in group $M$, while total serum protein increased with age in groups $B$ and $M B$, the latter especially. A similar though much more pronounced fall in serum glucose in 2 to 12 -week-old dairy calves was attributed by Khan et al. (2007) to the use of a step-down weaning procedure.

The trend in total serum protein is attributable to the fact that microbial protein synthesis in the rumen increases with age (Devant et al. 2000, Kaneko et al. 2008). All the other parameters except glucose, SUN and total serum protein were also significantly affected by group, i.e. by cereal type (Figure 1). Averaging over time points, group $M$ animals had higher AST activities and lower NEFA, creatinine, albumin and GGT levels than the others, while group B had the highest GGT activities and creatinine and albumin levels. Although the higher lactate levels of group B were not associated with clinical signs of acidosis (Castillo et al. 2009), it may nonetheless be significant that this group also had the highest levels of GGT, a sensitive indicator of hepatobiliary disorders (Latimer et al. 2003, Russell \& Roussel 2007), though all values were below the pathological range and the reverse between-group trend was shown by AST, a nonspecific marker of acute liver damage that can be elevated in acidotic animals (Latimer et al. 2003, Mori et al. 2007). Serum creatinine is an index of body muscle mass and protein catabolism (Latimer et al. 2003, Kaneko et al. 2008), and the fact that it was highest in group $B$ is in keeping with reports that a barley-based diet can be more efficient than a corn-based diet (Boss \& Bowman 1996, Surber \& Bowman 1998, Bengoechea et al. 2005, Castillo et al. 2009). Differences in NEFA values - although within physiological ranges - can be attributed to the different ether extract content of the ration in this period (Table 1) as in line with the observations made by Yambayamba et al. (1996).

It is noteworthy that there were no significant differences in serum glucose between the three groups of animals, since Tiffany \& Spears (2005) reported plasma glucose to be lower in Angus steers fed barley-based diets than in those fed maize-based diets, which they attributed to the lower ruminal propionate levels of barley-fed steers limiting postabsorptive metabolism and gluconeogenesis. However, glucose metabolism depends on the endocrine actions of insulin and glucagon (Huntington 1997), which in turn depend on breed (Pareek et al. 2007); the insensitivity of serum glucose to group in our study is in keeping with the results of a study of double-muscled Belgian Blue bulls in which serum glucose remained stable even after energy supply restriction (Fiems et al. 2007).

Although several parameters studied showed between-group differences in values averaged across time points, as discussed above, only AST did not exhibit significant group $\times$ time interaction. Thus AST can be considered as possible marker of grain-typerelated metabolic alteration throughout the finishing period of these bull calves. 

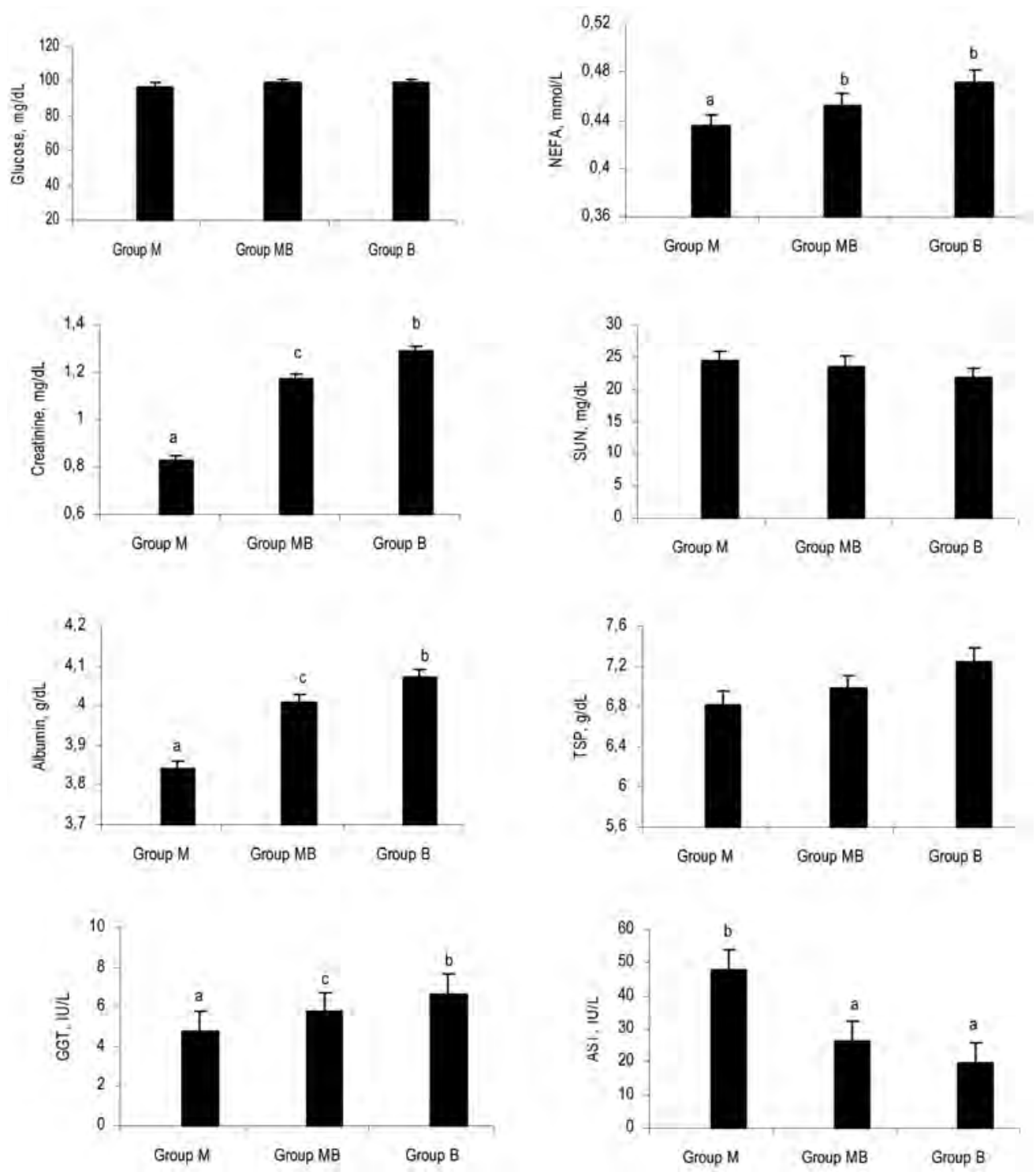

Figure 1

Mean serum glucose, NEFA, urea nitrogen, creatinine, protein, albumin, AST and GGT values in the study groups (bars show pooled SEs). Values labelled with different letters differ significantly $(P<0.05)$.

In conclusion, under the conditions of this study none of the diets employed was associated with either clinical signs of acidosis or pathological alterations in the metabolic parameters studied, possibly because of the high CP content of these diets and the high long-fibre NDF content of the forage, barley straw. This result in conjunction with the best productive results obtained in animals fed de B-diet, aim us to suggest that the risk of an acidogenic diet would depend strongly on the nutritional management (in terms of $\mathrm{CP}$ and quality of straw in the ration) and not only the type of grain. 
Although average serum NEFA, creatinine, albumin, AST and GGT levels all differed among groups, only AST can be considered as possible age-independent marker of grain-typerelated metabolic alterations, since the other parameters all showed significant time $\times$ group interaction.

Table 3

Mean ( \pm SE) of blood metabolites in Belgian Blue calves fed different high grain diets ${ }^{1}$ during the finishing period

\begin{tabular}{|c|c|c|c|c|c|c|}
\hline \multirow[t]{2}{*}{ Item and day } & \multicolumn{3}{|c|}{ Treatment } & \multicolumn{3}{|c|}{$P$} \\
\hline & $M$ & $\mathrm{MB}$ & B & Time & Group & TimexGroup \\
\hline Serum glucose, mg/dL & & & & 0.007 & 0.38 & 0.41 \\
\hline Day 0 & $95.4 \pm 3.81$ & $96.6 \pm 4.54$ & $102.2 \pm 3.83$ & & & \\
\hline Day 3 & $101.3 \pm 3.61$ & $101.4 \pm 1.03$ & $96.8 \pm 7.81$ & & & \\
\hline Day 7 & $101.2 \pm 3.04$ & $101.6 \pm 2.11$ & $94.6 \pm 2.87$ & & & \\
\hline Day 22 & $97.7 \pm 1.35$ & $97.8 \pm 2.06$ & $94.0 \pm 7.46$ & & & \\
\hline Day 50 & $96.6 \pm 0.93$ & $103.5 \pm 3.32$ & $90.4 \pm 2.62$ & & & \\
\hline Day 80 & $88.6 \pm 3.23$ & $93.2 \pm 3.34$ & $88.0 \pm 3.77$ & & & \\
\hline Serum NEFA, mmol/L & & & & $<0.001$ & 0.025 & $<0.001$ \\
\hline Day 0 & $0.45 \pm 0.01$ & $0.56 \pm 0.07$ & $0.46 \pm 0.03$ & & & \\
\hline Day 3 & $0.41 \pm 0.01$ & $0.41 \pm 0.01$ & $0.43 \pm 0.02$ & & & \\
\hline Day 7 & $0.36 \pm 0.03$ & $0.42 \pm 0.01$ & $0.45 \pm 0.01$ & & & \\
\hline Day 22 & $0.41 \pm 0.03$ & $0.43 \pm 0.02$ & $0.51 \pm 0.01$ & & & \\
\hline Day 50 & $0.39 \pm 0.02$ & $0.49 \pm 0.01$ & $0.49 \pm 0.01$ & & & \\
\hline Day 80 & $0.59 \pm 0.05$ & $0.41 \pm 0.01$ & $0.50 \pm 0.01$ & & & \\
\hline $\mathrm{SUN}, \mathrm{mg} / \mathrm{dL}$ & & & & 0.001 & 0.48 & $<0.001$ \\
\hline Day 0 & $26.2 \pm 1.24$ & $24.4 \pm 2.52$ & $26.6 \pm 0.68$ & & & \\
\hline Day 3 & $22.1 \pm 0.91$ & $19.2 \pm 2.33$ & $23.6 \pm 1.21$ & & & \\
\hline Day 7 & $22.2 \pm 0.86$ & $24.6 \pm 2.89$ & $21.2 \pm 1.43$ & & & \\
\hline Day 22 & $24.0 \pm 1.30$ & $23.2 \pm 3.18$ & $18.8 \pm 1.46$ & & & \\
\hline Day 50 & $26.0 \pm 2.05$ & $26.7 \pm 3.05$ & $18.6 \pm 1.43$ & & & \\
\hline Day 80 & $25.8 \pm 1.36$ & $23.6 \pm 2.11$ & $21.6 \pm 1.03$ & & & \\
\hline Serum creatinine, $\mathrm{mg} / \mathrm{dL}$ & & & & $<0.001$ & $<0.001$ & $<0.001$ \\
\hline Day 0 & $0.9 \pm 0.04$ & $1.0 \pm 0.03$ & $1.3 \pm 0.02$ & & & \\
\hline Day 3 & $0.7 \pm 0.02$ & $1.2 \pm 0.01$ & $1.2 \pm 0.03$ & & & \\
\hline Day 7 & $0.9 \pm 0.03$ & $1.3 \pm 0.06$ & $1.4 \pm 0.03$ & & & \\
\hline Day 22 & $0.9 \pm 0.02$ & $1.1 \pm 0.03$ & $1.2 \pm 0.03$ & & & \\
\hline Day 50 & $0.9 \pm 0.05$ & $1.3 \pm 0.04$ & $1.4 \pm 0.03$ & & & \\
\hline Day 80 & $0.6 \pm 0.07$ & $1.0 \pm 0.02$ & $1.3 \pm 0.05$ & & & \\
\hline $\mathrm{TSP}, \mathrm{g} / \mathrm{dL}$ & & & & $<0.001$ & 0.09 & 0.10 \\
\hline Day 0 & $6.9 \pm 0.13$ & $6.5 \pm 0.25$ & $6.8 \pm 0.12$ & & & \\
\hline Day 3 & $6.3 \pm 0.35$ & $6.5 \pm 0.12$ & $7.0 \pm 0.11$ & & & \\
\hline Day 7 & $6.8 \pm 0.06$ & $6.8 \pm 0.30$ & $6.7 \pm 0.18$ & & & \\
\hline Day 22 & $6.7 \pm 0.20$ & $6.9 \pm 0.24$ & $7.3 \pm 0.10$ & & & \\
\hline Day 50 & $7.3 \pm 0.12$ & $7.3 \pm 0.30$ & $7.9 \pm 0.17$ & & & \\
\hline Day 80 & $7.0 \pm 0.15$ & $7.7 \pm 0.30$ & $7.6 \pm 0.31$ & & & \\
\hline Albumin, g/dL & & & & $<0.001$ & $<0.001$ & $<0.001$ \\
\hline Day 0 & $3.8 \pm 0.02$ & $3.9 \pm 0.01$ & $4.1 \pm 0.01$ & & & \\
\hline Day 3 & $3.6 \pm 0.03$ & $3.8 \pm 0.04$ & $4.1 \pm 0.02$ & & & \\
\hline Day 7 & $4.0 \pm 0.05$ & $4.0 \pm 0.03$ & $4.0 \pm 0.02$ & & & \\
\hline Day 22 & $3.8 \pm 0.04$ & $4.1 \pm 0.02$ & $4.0 \pm 0.03$ & & & \\
\hline Day 50 & $3.9 \pm 0.15$ & $4.0 \pm 0.18$ & $4.1 \pm 0.32$ & & & \\
\hline Day 80 & $3.8 \pm 0.02$ & $4.1 \pm 0.04$ & $4.0 \pm 0.02$ & & & \\
\hline
\end{tabular}

M: maize-based diet, B: barley-based diet, MB: equal mixture of maize and barley 
Table 4

Mean ( \pm SE) of blood serum enzymes in Belgian Blue calves fed different high grain diets during the growing and finishing periods

\begin{tabular}{|c|c|c|c|c|c|c|}
\hline \multirow[t]{2}{*}{ Item and day } & \multicolumn{3}{|c|}{ Treatment } & \multicolumn{3}{|c|}{$P$} \\
\hline & $M$ & MB & B & Time & Group & TimexGroup \\
\hline Serum AST, IU/L & & & & 0.255 & 0.006 & 0.081 \\
\hline Day 0 & $59.1 \pm 13.3$ & $27.7 \pm 1.1$ & $17.8 \pm 2.4$ & & & \\
\hline Day 3 & $54.0 \pm 16.3$ & $22.8 \pm 2.6$ & $12.4 \pm 1.0$ & & & \\
\hline Day 7 & $49.8 \pm 13.9$ & $23.7 \pm 1.4$ & $14.0 \pm 2.6$ & & & \\
\hline Day 22 & $41.3 \pm 8.8$ & $27.7 \pm 5.0$ & $15.9 \pm 2.1$ & & & \\
\hline Day 50 & $46.8 \pm 11.8$ & $24.4 \pm 3.1$ & $12.0 \pm 1.2$ & & & \\
\hline Day 80 & $35.4 \pm 3.7$ & $30.6 \pm 3.5$ & $18.3 \pm 2.3$ & & & \\
\hline Serum GGT, IU/L & & & & $<0.001$ & $<0.001$ & $<0.001$ \\
\hline Day 0 & $4.5 \pm 0.20$ & $6.4 \pm 0.19$ & $5.8 \pm 0.37$ & & & \\
\hline Day 3 & $4.2 \pm 0.37$ & $7.1 \pm 0.45$ & $7.4 \pm 0.42$ & & & \\
\hline Day 7 & $6.2 \pm 0.20$ & $5.9 \pm 0.40$ & $8.0 \pm 0.66$ & & & \\
\hline Day 22 & $3.9 \pm 0.19$ & $5.0 \pm 0.51$ & $6.1 \pm 0.54$ & & & \\
\hline Day 50 & $5.0 \pm 0.32$ & $4.9 \pm 0.24$ & $7.4 \pm 0.60$ & & & \\
\hline Day 80 & $5.0 \pm 0.27$ & $5.1 \pm 0.37$ & $5.3 \pm 0.44$ & & & \\
\hline
\end{tabular}

M: maize-based diet, B: barley-based diet, MB: equal mixture of maize and barley

\section{Acknowledgements}

This work was supported by the Xunta de Galicia (Spain) through grant XUGA 2002/CG320. The authors also thank Maite Fernández Terán for expert technical assistance.

\section{References}

Arai T, Inoue A, Takeguchi A, Mizutani H, Shimoo M, Sako T, Yoshimura I, Kimura N (2003) Comparison of enzyme activities in plasma and leukocytes in dairy and beef cattle. J Vet Med Sci 65, 1241-1243

Bacha F (1999) Nutrición del ternero neonato, http://www1.etsia.upm.es/fedna/capitulos/99cap11.pdf [last accessed 21.01.2011]

Bailey CR, Duff GC (2005) Protein requirements for finishing beef cattle, http://cals-cf.calsnet.arizona. edu/ animsci/ansci/swnmc/papers/2005/Bailey_SWNMC\%20Proceedings\%202005.pdf [last accessed 21.01.2011]

Bengochea WL, Lardy GP, Bauer ML, Soto-Navarro SA (2005) Effect of grain processing degree on intake, digestion, ruminal fermentation, and performance characteristics of steers fed medium-concentrate growing diets. J Anim Sci 83, 2815-2825

Boss DL, Bowman JGP (1996) Barley varieties for finishing steers: Il. Ruminal characteristics and rate, site and extent of digestion. J Anim Sci 74, 1973-1981

Brown MS, Galyean ML, Duff GC, Hallford DM, Soto-Navarro SA (1998) Effects of degree of processing and nitrogen source and level of starch availability and in vitro fermentation of corn and sorghum grain, Professional Animal Scientist 14, 83-94

Brown MS, Krehbiel CR, Duff GC, Galyean ML, Hallford DM, Walker DA (2000a) Effect of degree of corn processing on urinary nitrogen composition, serum metabolite and insulin profiles, and performance by finishing steers. J Anim Sci 78, 2464-2474

Brown MS, Krehbiel CR, Galyean ML, Remmenga MD, Peters JP, Hibbard B, Robinson J, Moseley WM (2000b) Evaluation of models of acute and subacute acidosis on dry matter intake, ruminal fermentation, blood chemistry, and endocrine profiles of beef steers. J Anim Sci 78, 3155-3168 
Castillo C, Benedito JL, Pereira V, Méndez J, Vázquez P, López-Alonso M, Hernández J (2008) Effects of malate supplementation on acid-base balance and productive performance in growing/finishing bull calves fed a high-grain diet. Arch Anim Nutr 62, 70-81

Castillo C, Benedito JL, Pereira V, Vázquez P, Gutiérrez C, Hernández J (2009) Acid-base status and serum L-lactate in growing/finishing bull calves fed different high-grain diets. Liv Sci 120, 66-74

Devant M, Ferret A, Gasa J, Calsamiglia S, Casals R (2000) Effects of protein concentration and degradability on performance, ruminal fermentation, and nitrogen metabolism in rapidly growing heifers fed high concentrate diets from 100 to $230 \mathrm{~kg}$ body weight. J Anim Sci 78, 1667-1676

Fiems LO, Vanacker JM, De Boever JL, Van Caelenbergh W, Aerts JM, De Brabander DL (2007) Effect of energy restriction and re-alimentation in Belgian Blue double-muscled beef cows on digestibility and metabolites. J Anim Physiol Anim Nutr 91, 54-61

Huntington GB (1997) Starch utilization by ruminants: from basics to the bunk. J Anim Sci 75, 852-867

Kaneko JJ, Harvey JW, Bruss ML (2008) Clinical biochemistry of domestic animals. 6th ed. Academic Press Orlando

Khan MA, Lee HJ, Lee WS, Kim HS, Ki KS, Park SJ, Ha JK, Choi YJ (2007) Starch source evaluation in calf starter: I. Feed consumption, body weight gain, structural growth and blood metabolites in Holstein calves. J Dairy Sci 90, 5259-5268

Krause M, Beauchemin KA, Rode LM, Farr BI, Norgaard P (1998) Fibrolytic enzyme treatment of barley grain and source of forage in high-grain diets fed to growing cattle. J Anim Sci 76, 2912-2920

Latimer KS, Mahaffey EA, Prasse KW (2003) Duncan \& Prasse's Veterinary laboratory medicine: clinical pathology. 4th rev ed, State University Press, lowa, USA

Lorenz I (2004) Investigations on the influence of serum D-lactate levels on clinical signs in calves with metabolic acidosis. Vet $\mathrm{J} 168,323-327$

Lumsden JH (2000) Laboratory test methods validation. Rev Méd Vét 151, 623-630

Mori A, Urabe S, Asada M, Tanaka Y, Tazaki H, Yamamoto I, Kimura N, Ozawa T, Morris ST, Hickson R, Kenyon PR, Blair H, Choi CB, Arai T (2007) Comparison of plasma metabolite concentrations and enzyme activities in beef cattle raised by different feeding systems in Korea, Japan and New Zealand. J Vet Med Series A 54, 342-345

Pareek N, Voigt J, Bellmann O, Schneider F, Hammon HM (2007) Energy and nitrogen metabolism and insulin response to glucose challenge in lactating German Holstein and Charolais heifers. Liv Sci 112, 115-122

Russell KE, Roussel AJ (2007) Evaluation of the ruminant serum chemistry profile. Vet Clin Food Anim 23, 403426, SPSS Inc (2004) SPSS version 12.1. Chicago, IL, USA

Surber LMM, Bowman JGP (1998) Monensin effects on digestion of corn or barley high-concentrate diets. J Anim Sci 76, 1945-1954

Tiffany ME, Spears JW (2005) Differential responses to dietary cobalt in finishing steers fed corn-versus barleybased diets. J Anim Sci 83, 2580-2589

Van Soest PJ, Robertson JB, Lewis BA (1991) Methods for dietary fiber, neutral detergent fiber, and non-starch polysaccharides in relation to animal nutrition. J Dairy Sci 74, 3583-3597

Yambayamba ESK, Price MA, Foxcroft GR (1996) Hormonal status, metabolic changes, and resting metabolic rate in beef heifers undergoing compensatory growth. J Anim Sci 74, 57-69

Received 4 June 2010, accepted 21 January 2011.

Corresponding author:

Cristina Castillo

email: cristina.castillo@usc.es

Departamento de Patología Animal, Facultad de Veterinaria, Universidad de Santiago de Compostela, Campus Universitario s/n, 27002 Lugo, Spain 